\title{
Screening of adulterants and extent of added water in market milk at central zone of Sindh, Pakistan
}

\author{
Ghulam Shabir Barham ${ }^{1^{*}}$, Muhammad Khaskheli ${ }^{1}$, Aijaz Hussain Soomro ${ }^{2}$ and \\ Zaheer Ahmed Nizamani ${ }^{3}$ \\ ${ }^{1}$ Department of Animal Products Technology, ${ }^{2}$ Institute of Food Sciences and Technology, \\ ${ }^{3}$ Department of Veterinary Pathology, Sindh Agriculture University, Tandojam, PAKISTAN.
}

\begin{abstract}
An experiment was designed to screen the various adulterants in the market milk sold in central zone (vicinity of Hyderabad, Mirpurkhas and Shaheed Benazirabad districts) of Sindh province at the end of year 2013. A total of 300 milk samples were collected each of 100 from vicinity of Hyderabad, Mirpurkhas and Shaheed Benazirabad. Twenty milk samples $(n=20)$ from each of milk producer $(M P)$, milk collector $(M C)$, middlemen $(M M)$, processor $(P)$ and dairy shop $(D S)$ were examined for different adulterants (water, urea, starch, arrowroot, rice flour, sorbitol, glucose, cane sugar, ammonium sulfate, caustic soda, sodium chloride, skimmed milk powder, vegetable oil, formalin, hydrogen peroxide, boric acid, salicylic acid, detergent and hypochlorite). Among these adulterants extraneous water was found in majority of milk samples. Freezing point of $39 \%$ milk samples of MP, 47\% of MC, 50\% of MM, 46\% of $P$ and $56 \%$ of DS appeared towards $0{ }^{\circ} \mathrm{C}$ rather than that of control milk, and assumed to be adulterated with added water. Among all 300 milk samples water (79.3\%) was common adulterant found in majority of milk samples followed by detergent (30.3\%), cane sugar $(22 \%)$, starch $(18.3 \%)$, rice flour $(17.7 \%)$, skimmed milk powder $(15.3 \%)$, caustic soda sodium chloride and formalin (14\%), hydrogen peroxide (12\%), urea and vegetable oil (10.7\%), ammonium sulfate and boric acid (8.3\%), glucose (6.3\%), arrowroot (3.3\%), sorbitol (2.7\%) hypochlorite (1.7\%) and salicylic acid $(1.3 \%)$, respectively. The extent of extraneous water found to be comparatively higher $(P<0.05)$ in milk sold by different milk dealers; $D S, M C, M M$ and $P$ than that of milk producers. The percentage of adulteration at $D S, M C$ and $M M$ was statistically non-significant $(P>0.05)$ with each other, but found to be significantly $(P<0.05)$ higher than that of $P$ and MP. . The proportion of milk adulteration was found comparatively higher $(P<0.05)$ at

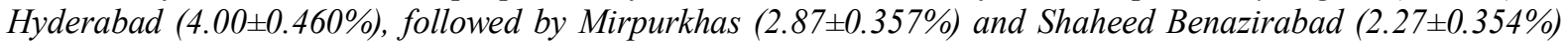
districts of Sindh, Pakistan.
\end{abstract}

Key words: Adulterants, extent of added water, market milk and proportion of adulteration

\section{Introduction}

Milk if present in its natural form has high food value and supplies nutrients like good quality proteins, fat, carbohydrates, vitamins and minerals in significant amount. Besides its general need for human health, milk proteins also provide amino acids which are needed for proper growth of adults and infants [1]. Currently, the milk production of country is 49,512 thousand tons [2]. Although Pakistan has a good ranking among milk producing countries but milk production and distribution systems are still very traditional and underdeveloped. It is dominated mainly by the informal private sectors, consisting of various agents (i.e. producers, collectors, middlemen, processors, traders, and dairy shops) with each performing a specialized role at a particular point in the supply chain [3]. During summer season (when milk production is low and the demand is high), adulteration is major problem in the fluid milk supply in Pakistan. Milk suppliers increase their margin from the sale of milk through dilution, extraction of valuable component (i.e. cream) and/or use of additives such as low quality flour to enhance the total solids content. Hence, the milk for consumption has been adulterated to such an extent that there is very little nutritive value left in it [4]. However, the adulteration of milk deteriorates quality of milk, and may cause serious problems for human health. For example, carbonate in milk may produce gastrointestinal problems including gastric ulcer, diarrhea, colon ulcer and electrolytes disturbance. While, the hydrogen peroxide disturbs the antioxidants in the body; disturbing the natural immunity hence increasing aging. High level of chloride in the milk disturbs the acid base balance and blood $\mathrm{pH}$ in the body, and the addition of ammonia in the milk may cause regression, loss of acquired immunity, kidney problems and sensory disturbances. Formalin causes vomiting, diarrhea and abdominal pain. It also affects the optic nerves and cause blindness and is one of the potent carcinogens. Boric acid causes nausea, vomiting, diarrhea, kidney damage, acute failure of circulatory system and even death. Benzoic acid produces adverse effects such as asthma, urticaria, metabolic acidosis, and convulsions in sensitive persons. Moreover, melamine an industrial chemical causes the urinary tract problems in infants and children [5-13]. Therefore, present study was planned to detect 
various adulterants and to calculate the extent of water in the market milk sold in central zone of Sindh province.

\subsection{Sample Collection}

\section{Material And Methods}

An experiment was designed to screen the various adulterants in the market milk at the central zone (vicinity of Hyderabad, Mirpurkhas and Shaheed Benazirabad districts) of Sindh province. A total of 300 unprocessed milk samples were collected each of 100 from the central zone of Sindh province; vicinity of Hyderabad, Mirpurkhas and Shaheed Benazirabad districts. Further, sampling of milk was performed from each of twenty milk producers (MP), milk collectors (MC), middlemen (MM), processors (P) and dairy shops (DS). All the market milk samples were collected in sterilized glass bottle with cap, labeled, kept in icebox and immediately brought to the Dairy analytical laboratory of the Department of Animal Products Technology, Faculty of Animal Husbandry and Veterinary sciences, Sindh Agriculture University Tandojam, and stored at 4$8^{\circ} \mathrm{C}$ till analysis.

\subsection{Detection Of Adulterants In Market Milk}

All the milk samples were screened for the presence of different adulterants through commercially available milk adulteration testing kit and methods as reported by Khaskheli [14-15].

\subsection{Screening Of Added Water In Market Milk}

Presence and extent of extraneous water in milk samples was detected by depression of freezing point (through Cryoscope) and calculated by using following formula [16]. (AOAC, 2000).

$\%$ water added $=$

Freezing point base - observed freezing point $\times 100$

\section{Freezing point base}

\section{Iii. Statistical Analysis}

The data obtained was subjected to analysis of variance (ANOVA), significant differences of the means were computed using least significant difference (LSD) through computerized statistical package i.e. Student Edition of Statistix (SXW), Version 8.1 (Copyright 2005, Analytical Software, USA).

\section{Results}

\section{Detection Of Adulterants In Market Milk At Central Zone Of Sindh}

Market milk samples randomly collected from different milk sale points of central zone (vicinity of Hyderabad, Mirpurkhas and Shaheed Benazirabad districts) of Sindh viz, milk producers (MP), milk collectors $(\mathrm{MC})$, middlemen (MM), processors (P) and dairy shops (DS) were examined for different adulterants. The water was the most common adulterant $(79.3 \%)$ found in the majority of milk samples, followed by detergent which was detected in $30.3 \%$ of milk samples from a total of 300 samples. Furthermore, $22.0 \%$ samples were positive for cane sugar, $18.3 \%$ for starch, $17.7 \%$ for rice flour, $15.3 \%$ for skimmed milk powder, $14.0 \%$ each for caustic soda, sodium chloride and formalin, $12.0 \%$ for hydrogen peroxide, $10.7 \%$ for urea and vegetable oil, $8.3 \%$ for ammonium sulfate and boric acid, $6.3 \%$ for glucose, $3.3 \%$ for arrowroot, $2.7 \%$ for sorbitol $1.7 \%$ for hypochlorite and $1.3 \%$ for salicylic acid, respectively (Figure-1).

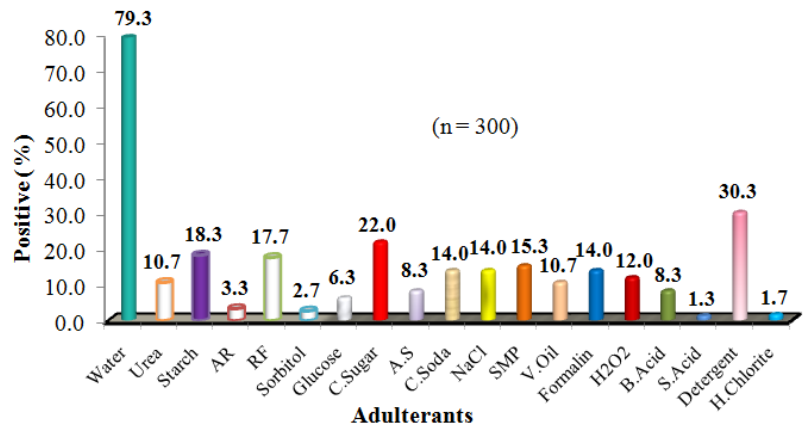

Legends: $\quad \mathrm{AR}=$ Arrowroot, $\mathrm{RF}=$ Rice flour, $\mathrm{AS}=$ Amonium sulfate, $\mathrm{C} . \mathrm{Sugar}=\mathrm{Cane}$ sugar , C. Soda $=$ Caustic soda, $\mathrm{NaCl}=$ Sodium chloride, $\mathrm{SMP}=$ Skimmed milk powder, V.Oil $=$ Vegetable oil, H2O2 = Hydrogen peroxide, B.Acid = Boric acid, S.Acid $=$ Salicylic acid, H.Chorite $=$ Hypochlorite 
Figure:1 Percentage of various adulterants detected in market milk samples of central zone of Sindh, Pakistan.

4.2 Market Milk Samples Varied In Freezing Point Of Control Milk

The freezing point of control milk ranged between -0.561 to $-0.522^{0} \mathrm{C}$. However, control milk varied considerably in average freezing point from the milk of different intermediaries in the present study. Moreover, $39 \%$ milk samples of MP, $47 \%$ of MC, $50 \%$ of MM, $46 \%$ of P and $56 \%$ of milk sold at DS did not show the similarity with freezing point of control milk $\left(-0.522\right.$ to $\left.-0.651{ }^{0} \mathrm{C}\right)$ and assumed to be positive, adulterated with extraneous water, while $61,53,50,54$ and $44 \%$ samples were in range of freezing point of control milk samples and assumed to be negative, respectively (Figure-2).

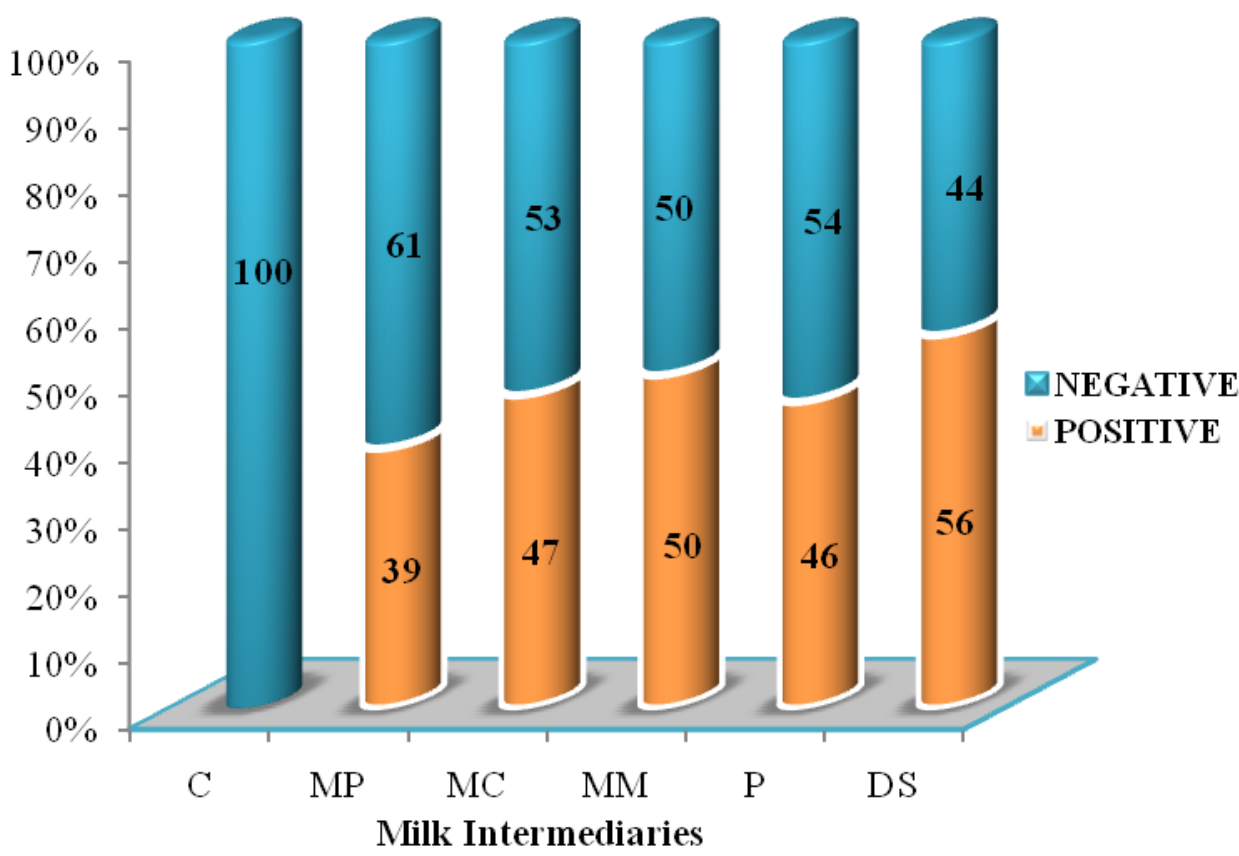

Legends: $\quad \mathrm{C}=$ Control, $\mathrm{MP}=$ Milk producers, $\mathrm{MC}=$ Milk collectors, $\mathrm{MM}=$ Middlemen, $\mathrm{P}=$ Processors and DS = Dairy shops.

*Milk samples with freezing point below the range of control milk (-0.522 to -0.561$)$.

Figure:2 Milk samples varied in freezing point from control milk collected from different intermediaries at central zone of Sindh, Pakistan.

\subsection{Extent Of Added Water (\%) In Market Milk Sold By Different Intermediaries}

Extent of added water in milk sold by different milk marketing channels was measured by observing the depression of freezing points. The average water percent in milk of DS was noted as $28.44 \pm 2.14$, followed by milk of MC (26.25 $\pm 2.68 \%), \mathrm{P}(23.90 \pm 2.28 \%), \mathrm{MM}(22.57 \pm 2.22 \%)$ and MP $(15.42 \pm 1.95 \%)$, respectively. The extent of water in milk sold at dairy shop (DS) was found to be higher than that of other milk marketing channels, but statistical analysis (LSD, 0.05) showed no significant differences $(\mathrm{P}>0.05)$ among all milk intermediaries; dairy shop, milk collectors, middlemen and processors except milk producers. However, the extent of added water was found to be comparatively higher $(\mathrm{P}<0.05)$ in milk sold at dairy shops, milk collectors, processors and middlemen than that of milk sold by milk producers (Figure-3). 


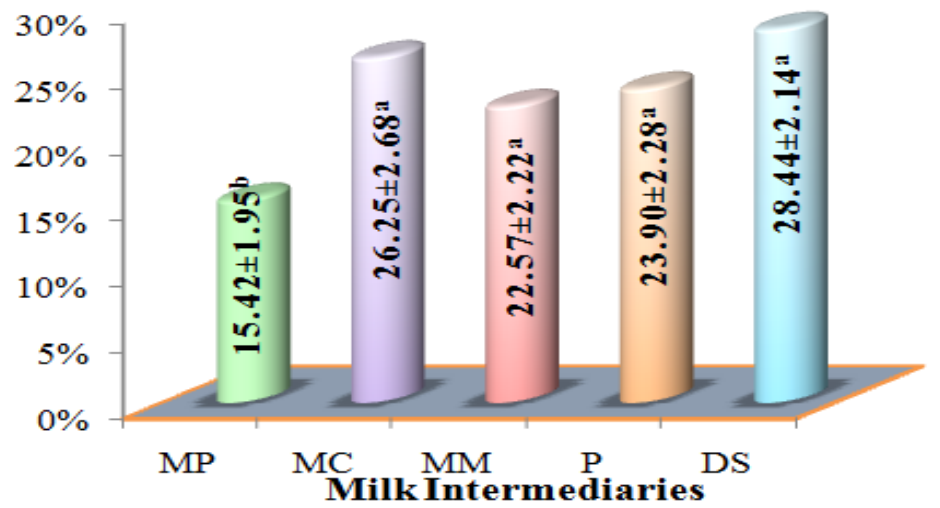

Legends: $\quad \mathrm{MP}=$ Milk producers, $\mathrm{MC}=$ Milk collectors, $\mathrm{MM}=$ Middlemen, $\mathrm{P}=$ Processors

$\mathrm{SE}+$

Figure:3 Extent of added water in market milk sold by different intermediaries at central zone of Sindh, Pakistan.

\subsection{Percentage (\%) Of Milk Adulteration At Different Intermediaries}

Percentage of adulteration in milk sold by different milk marketing channels was calculated during present study and it was noted that $4.65 \%$ adulteration done at dairy shop, followed by milk collectors $(3.72 \%)$, middlemen $(3.68 \%)$, processors $(2.30 \%)$ and milk producers $(0.95 \%)$, respectively. The percentage of adulteration at dairy shop (DS), milk collectors and middlemen was statistically non-significant $(\mathrm{P}>0.05)$ with each other, but found to be significantly $(\mathrm{P}<0.05)$ higher than that of processors and milk producers (Figure- 4$)$.

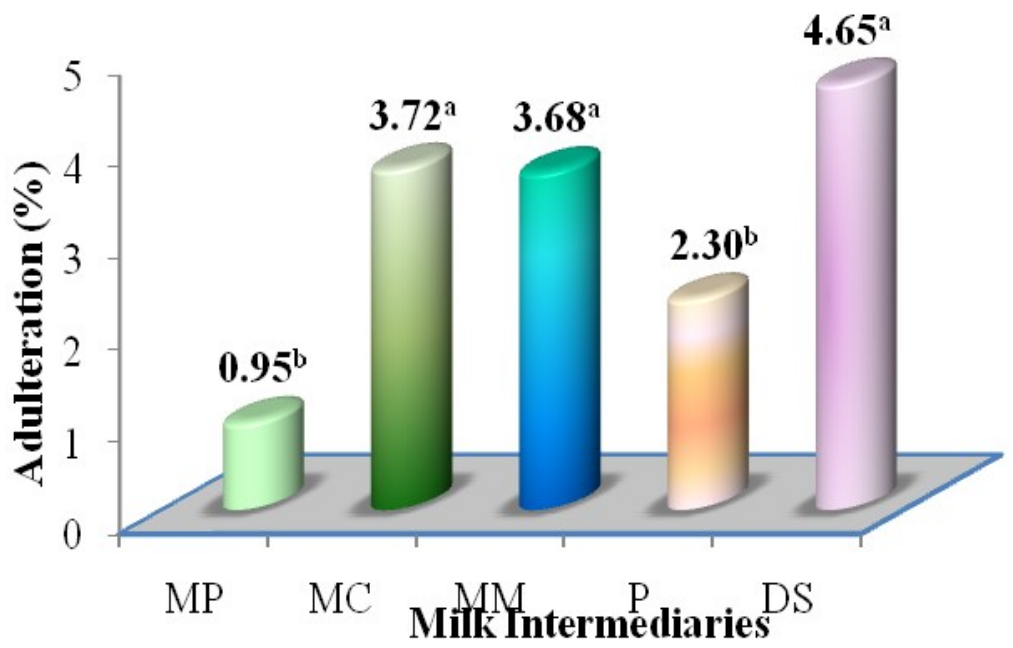

Legends: $\quad \mathrm{MP}=$ Milk producers, $\mathrm{MC}=$ Milk collectors, $\mathrm{MM}=$ Middlemen, $\mathrm{P}=$ Process or $\mathrm{s}$

$\operatorname{LSD}(0.05) \quad=\quad 1.359$

$\mathrm{SE} \pm \quad=\quad 1.690$

Figure:4 Adulteration (\%) in market milk sold by different intermediaries at central zone of Sindh, Pakistan.

\subsection{Proportion (\%) Of Milk Adulteration Among Districts}

The proportion of milk adulteration among districts (Hyderabad, Mirpurkhas and Shaheed Benazirabad) of central zone of Sindh province was calculated and results are depicted in Figure-5. It was observed that the Hyderabad $(4.00 \pm 0.460 \%)$ district of the Sindh province was on top followed by Mirpurkhas $(2.87 \pm 0.357 \%)$ and Shaheed Benazirabad $(2.27 \pm 0.354 \%)$ districts. The results of statistical analysis (ANOVA) revealed that the proportion of milk adulteration is significantly higher $(\mathrm{P}<0.05)$ at Hyderabad than that of Mirpurkhas and Shaheed Benazirabad districts. While, there was no significant difference $(\mathrm{P}>0.05)$ was found in between Mirpurkhas and Shaheed Benazirabad districts of central zone of Sindh province. 


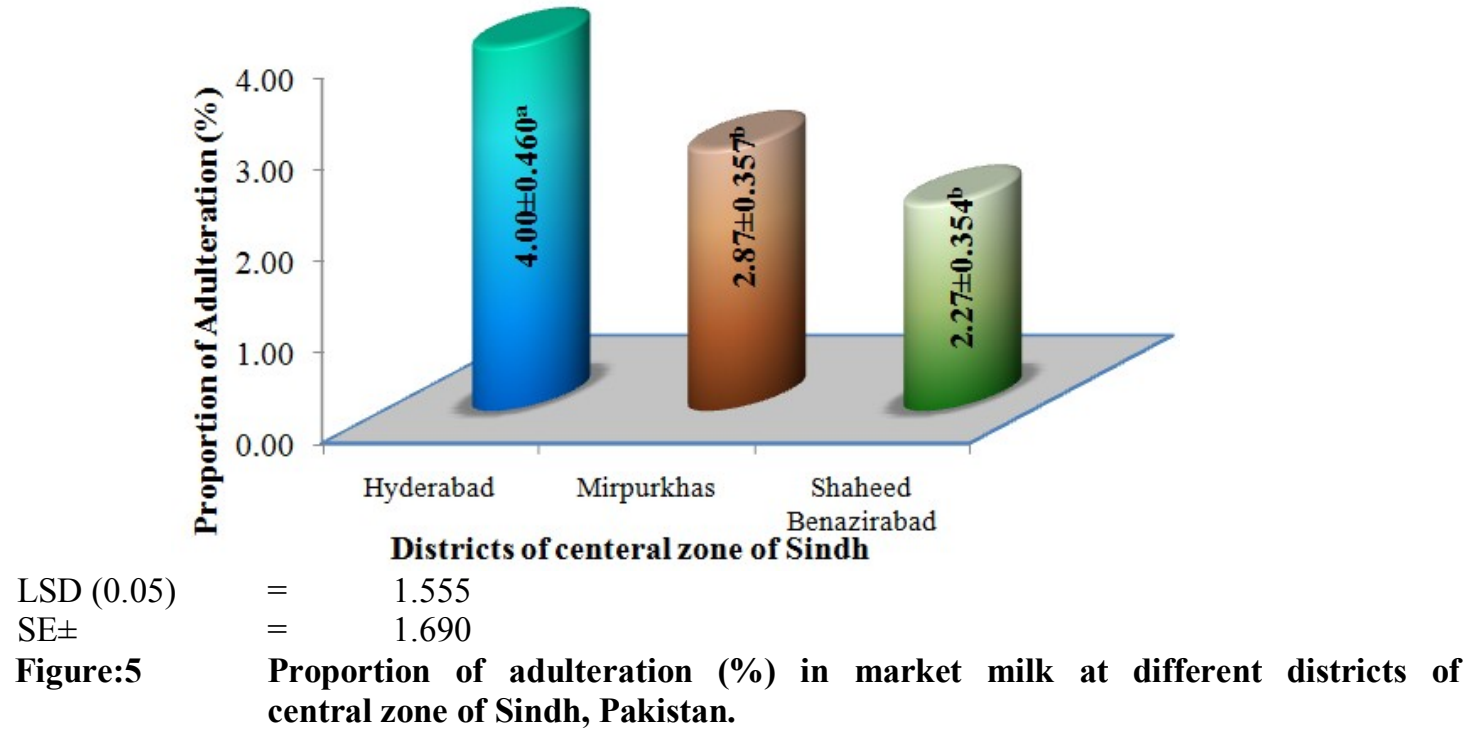

\section{Discussion}

Milk adulteration, poor hygiene, lack of preservation technology, cooling facilities and sanitation conditions are the main causes of losses in quality of milk [5]. The milk supply is reduced in summer due to fall $(55 \%)$ in milk production and increase in demand $(60 \%)$ compared to winter when milk supply is ample. To cope with demand, water is admixed with whole milk to increase the volume of milk during summer season [17]. It has been reported that milk adulteration is common in developing countries and that has direct influence on the quality characteristics of milk [18]. In the present study milk samples were collected from different intermediaries; milk producers, milk collectors, middlemen, processors and dairy shops from the central zone of Sindh province (vicinity of Hyderabad, Mirpurkhas and Shaheed Benazirabad districts) to observe the presence of various adulterants. In the present study the freezing point of milk samples collected from different intermediaries was significantly $(\mathrm{P}<0.05)$ higher than that of control milk samples. These results for freezing point are in accordance with the results of other scientists; they reported that milk containing extraneous water will have a grossly elevated freezing point. In our study the mean extent of extraneous water found to be comparatively higher $(\mathrm{P}<0.05)$ in milk sold at dairy shops, milk collectors, processors and middlemen than that of milk sold by milk producers [19-20]. Similarly, the average extent of extraneous water was found to be higher in market milk samples and the ratio of adulteration in milk was high in urban areas as compared to the rural areas [21]. For the fulfillment of the gap between demand and supply different milk marketing dealers adulterated the milk by adding water which is probably carried out during the handling of milk starting from milking till it reaches the consumer or end user [3]. Milk dealers add dirty ice to increase the shelf life of milk which is also one of the reasons of elevated level of extraneous water in milk samples [22]. The water was common adulterant found to be in majority of milk samples (79.3\%) evaluated in present study. Similar findings were found by various researchers. They reported that the main adulterant in milk was water and it was found to be in $70 \%$ samples, while, $93.33 \%$ samples of milk adulterated with water were found at central canteen of hospitals at Faisalabad, Pakistan [23 and 4]. It has been noticed that addition of water to normal whole milk was assumed to increase the quantity of milk [22]. 95\% fresh milk sold in the market of the Khartoum state of Sudan was also adulterated with water [25]. However, the addition of water to milk not only reduces the nutritional value of milk but contaminated water may also pose a health risk [26]. Milk samples collected from milk vendors were highly adulterated with water than samples collected from dairy farms [27]. Similarly, other adulterants like detergent $(30 \%)$, cane sugar $(22 \%)$, starch $(18.3 \%)$, rice flour $(17.7 \%)$, skimmed milk powder $(15.3 \%)$, caustic soda, sodium chloride and formalin (14\%), hydrogen peroxide (12\%), urea and vegetable oil $(10.7 \%)$, ammonium sulfate and boric acid $(8.3 \%)$, glucose $(6.3 \%)$, arrowroot $(3.3 \%)$, sorbitol $(2.7 \%)$, hypochlorite (1.7\%) and salicylic acid (1.3\%) were detected in milk samples from a total of 300 samples in the present study. The proportion of samples adulterated with various adulterants varied in different studies. When water is added in milk, its foamy appearance diminishes, so to give milk a foamy appearance artificially detergents are added in it [28]. However, $20 \%$ of detergents adulteration in pure cow milk is used to enhance the cosmetic nature of milk [29]. Similarly, 93.33, 86.66, 34 and 13\% milk samples were found positive for cane sugar, urea, formalin and starch at central canteens of hospital at Faisalabad, Pakistan [4]. It is of interest to note that the middlemen attempt to counter the dilution by adding cane sugar to extend the solids content of the milk or as additives for the purpose of masking the effect of dilution of water [30-31]. While, $12 \%$ samples in summer, $10 \%$ in rainy and $2 \%$ in winter season found to be adulterated with formaldehyde, $5 \%$ with sodium 
chloride and $2 \%$ with starch [31]. Starch, wheat flour, arrowroot and rice flour are added for increasing the solids not fat (SNF) content of milk. Starch is used to increase the viscosity and total up to an accepted level of consumers [22 and 33]. In Brazil, salt was added in milk to mask the high water content [34]. 2.08\% milk samples were found contaminated with formaldehyde [35]. The formalin is used as preservative of milk for increasing the shelf life but it not only decreases the nutritive value of milk but also is carcinogenic [24 and 33]. It has been reported that high level of chloride in milk could affect the acid base balance in body and may develop regression loss of acquired immunity, kidney problems, speech and sensory disturbances [36]. In the present study milk samples were also found adulterated with skimmed milk powder and glucose. Similarly, 44.69 and $70.42 \%$ milk samples were found positive for skimmed milk powder and glucose [26 and 37]. The adulteration of ammonium sulfate, $(0.5$ to $5 \%)$ was used as an additive for the purpose of masking the effects of dilution of water in the milk [38]. Hydrogen peroxide, formalin, boric acid, benzoic and salicylic acid were used as chemical preservatives for milk. These were usually used to increase the shelf life of milk during summer season when environmental temperature is very high. This unethical activity is usually adopted by the milk traders to prevent the financial losses due to the spoilage of milk during its transportation and sale [39]. In Turkey milk was adulterated with benzoic acid at the low levels which was widely used for the preparation of milk products [40]. In Kenya raw milk samples were analyzed for adulteration of hydrogen peroxide and 23.5\% samples were found positive for hydrogen peroxide. In Pakistan, vegetable oil was added in milk by removing the true fat and cream from it to maintain the fat ratio by milk traders [27]. While, in China milk was adulterated with vegetable oil to increase the fat level [41]. Caustic soda, sodium carbonate and bicarbonate were frequently used to neutralize the $\mathrm{pH}$ and acidity of milk by the milk traders in Pakistan [22]. In India, 27\% milk samples in winter and $12 \%$ in summer and $10 \%$ in rainy season were found to be adulterated with carbonates/bicarbonates [42]. In present study it was observed that the percentage of adulteration at dairy shop (DS), milk collectors and middlemen was significantly $(\mathrm{P}<0.05)$ higher than that of processors and milk producers, respectively. Similar observations were also recorded in various studies. In Pakistan raw milk is distributed by a traditional system which involves middlemen called"Gawalaš. These milk dealers; middlemen and dairy shop keepers adulterate the milk to maximize their profit.

\section{Conclusion}

It was concluded that, on the basis of freezing point temperature of control milk, majority of milk samples from different intermediaries were found adulterated with added water. The water was the most common adulterant found in majority of market milk samples sold in the central zone (vicinity of Hyderabad, Mirpurkhas and Shaheed Benazirabad districts) of Sindh province, followed by detergent, cane sugar, starch, rice flour, skimmed milk powder, caustic soda, sodium chloride, formalin, hydrogen peroxide, urea, vegetable oil, ammonium sulfate, boric acid, glucose, arrowroot, sorbitol, hypochlorite and salicylic acid. The percentage of adulteration at dairy shop (DS), milk collectors $(\mathrm{MC})$ and middlemen $(\mathrm{MM})$ was significantly $(\mathrm{P}<0.05)$ higher than that of processors and milk producers. The unethical activity of milk adulteration is frequently practiced in the central zone of Sind province of Pakistan. Among all three districts of central zone of Sindh province, the proportion of adulteration was found to be higher at Hyderabad district, followed by Mirpurkhas and Shaheed Benazirabad districts.

\section{Acknowledgement}

Authors are very grateful to Higher Education Commission (HEC), Islamabad, Pakistan for awarding Indigenous $\mathrm{Ph} . \mathrm{D}$ Scholarship. This portion of $\mathrm{PhD}$ research work on "Screening of adulterants and extent of added water in market milk at central zone of Sindh, Pakistan" is fully supported by the Higher Education Commission (HEC) Islamabad, Pakistan.

\section{References}

[1] Neumann, C.G., D.M. Harris and L.M. Rogers. Contribution of animal source foods in improving diet quality and function in children in the developing world. Nutrition Research, (22), 2002, 193-220.

[2] Farooq, O. Agriculture. In: Pakistan economic survey, 2012-2013. Economic Advisers Wing, Finance Division, Government of Pakistan, Islamabad.

[3] Zia, U. (2006). Analysis of milk marketing chain, Pakistan. FAO. Food Laws Manual. 2006.

[4] Lateef, M., A. Faraz, M.I. Mustafa, P. Akhtar, and M.K. Bashir. Detection of adulterants and chemical composition of milk supplied to canteens of various hospitals in Faisalabad city. Pakistan Journal of Nutrition, (9), 2009, 139-142.

[5] Haasnoot, W., N.G. Smits, A.E.K. Voncken and M.G. Bremer. Fast biosensor immunoassays for the detection of cows' milk in the milk of ewes and goats. Journal of Dairy Research, 71, 2004, 322-329.

[6] Beall, D.P, and R.H. Scofield, Milk-alkali syndrome associated with Calcium carbonate consumption. Reports of seven patients with parathyroid hormone levels and an estimate of prevalence among patients hospitalized with hypocalcaemia. Medicine. 74 (2), 1995, 89-96.

[7] Rideout, T.C., Q. Liu, P. Wood and M.Z. Fan. Nutrient utilization and intestinal fermentation are differentially affected by the consumption of resistant starch varieties and conventional fibers in pigs. British Journal of Nutrition, (99), 2008 984-92. 
[8] Ayub, M., Q. Ahmed, M. Abbas, I.M. Qazi and I.A. Hattak. Composition and adulteration analysis of milk samples. Sarhad Journal of Agriculture, 23 (4), 2007, 1127-1130.

[9] Gwin, M.C., G. Lienert and J. Kennedy. Formaldehyde exposure and asthma in children. A systematic review. Environment Health Perspective, 118, 2009, 313-317.

[10] See, A.S., A.B. Salleh, F.A. Bakar, N.A. Yusof, A.S. Abdulamir and L.Y. Heng Risk and health effect of boric acid. American Journal of Applied Sciences, 7, 2010, 620-627.

[11] Mota, F.J.M, F. Implvo, S.C. Cunha, M. Beatriz and P.P. Oliveira. Optimization of extraction procedures for analysis of benzoic and sorbic acids in foodstuffs. Food Chemistry 3 (82), 2003, 469-473.

[12] Saad, B., M.F. Bari, M.I. Saleh, K. Ahmad and M.K.M. Talib. Simultaneous determination of preservatives in food stuffs using HPLC. Journal of Chromatography Analysis, (1073), 2005, 393.

[13] Li, Z., L.L. Wu, Y.P. Wang, A.M Liu, C.C Zou, and Z.Y. Zhao. Melamine contaminated milk products induced urinary tract calculi in children. World Journal of Pediatrics, 5 (1), 2009, 31-35.

[14] Tipu, M.Y., I. Altaf, M. Ashfaq, and S. Siddiqui. Introduction. In Proceedings of the workshop on monitoring of chemical adulterants and hygienic status of market milk. Lahore, Pakistan: (WTO-Quality Control Laboratory, 2007), 7-39.

[15] Khaskheli, M. Dairy Laboratory Manual. (Department Animal Products Technology, Faculty Animal Husbandry and Veterinary Sciences, Sindh Agriculture University, Tandojam, 2010), 38.

[16] AOAC, Official methods of analysis of the association of official analytical chemists. (Inc. Gaithersburg, U.S.A., 2000).

[17] Butt, M.Y.M. (2011). Seminar on Milk Anti-adulteration policy Policy Draft: International executive summary dairy report, (IFCN) Pak. Lahore.

[18] PSQCA, 2006. Formalin in Nestle Pakistan milk. Network for consumer report. (Release No 0017/06).

[19] Nida, S., Soomro, A.H. Sheikh, S.A. \& Khaskheli, M. (2013). Extent of water adulteration and its influence on physical characteristics of market milk. Pakistan Journal of Nutrition, 12 (2): 178-181.

[20] Meredith, P., Williams, P., Zampa, N., Garry, E. \& Ouattara, G. (2007). The effect of raw milk storage conditions on freezing point, $\mathrm{pH}$ and impedance. Advance Instruments, INC., (pp: 1-7).

[21] Bhatt, S.R., Singh, A. \& Bhatt, S.M. (2008). Assessment of synthetic milk exposure to children of selected population in Uttar Pradesh, India. Indian Journal of Research, 7: 22-34.

[22] Tariq, M.A., 2001. Subject: A close look at dietary patterns http://www.dawn.com/2001/11/05/ebr13. Htm. Accessed Feb, 2011.

[23] Beniwal, A., Khetarpaul, N. (1999). Knowledge of consumers regarding the nature and extent of adulteration of Indian foods. Nutrition Health, 13 (3):153-60.

[24] Bhatti, M.Y. (2010). Formalin in milk consultancy report of Lahore High court. Free News alerts sums' PT to 9900.

[25] Ahmed, A.A.H. Milk adulteration by adding water and starch at Khartoum state, Pakistan Journal of Nutrition, 8 (4), $2009,439-443$.

[26] Pitty, (2011). 69 PC milk samples fail quality test some contain detergents. A national survey on milk adulteration. Conducted by Food Safety and Standards Authority of India. reported by PTI.

[27] Zia, U. (2007). Improved market access and smallholder dairy farmer participation for sustainable dairy development. Consultancy Report CFC/FIGMDP/ 16FT. Lessons Learned Study. Islamabad, Pakistan.

[28] Walker, G.P., Dunshea, F.R. \& Doyle, P.T. (2004). Effects of nutrition and management on the production and composition of milk fat and protein. Australian Journal of Agriculture Research. (55): 1009-1028.

[29] Manish, M.P., Singhal, R.S. \& Kulkarni, P.R. (2000). An approach to the detection of synthetic milk in dairy milk, 1. Detection of urea. International Journal of Dairy Technology, 53. (3): 987-91.

[30] Fakhar, H. \& Law Walker, F.G. (2006). The white revolution-dhoodh darya. Pakistan Dairy Development Company, (pp. 72).

[31] Singhal, R.S., Kulkarni, P.R. \& Rege, D.V. (1997). Handbook of Indices of food quality and authenticity. Wood Head Publishing Limited, Cambridge England, (pp.168-174).

[32] Wadekar, S. B. \& Menkudale, G.V. (2011). Physico-chemical quality of market milk in Nanded town. Vision Research Review. I (I): (pp.27).

[33] Afzal, A., Mahmood, M.S., Hussain, I. \& Akhtar, M. Adulteration and microbiological quality of milk. Pakistan Journal of Nutrition, 10 (12), 2011. 1195-1202.

[34] Ibtisam, E., El- Zubeir, M., El- Owni, O.-A.-O. (2009). Antimicrobial resistance of bacteria associated with raw milk contaminated by chemical preservatives. World Journal of Dairy and Food Science, 4 (1): 65-69.

[35] Fertig, C.C., Podczeck, F., Jee, R.D. \& Smith, M.R. (2004). European Journal of Pharmacology Science, $2,155$.

[36] Ayub, M., Ahmed, Q., Abbas, M., Qazi, I.M., \& Hattak, I.A.(2007). Composition and adulteration analysis of milk samples, Sarhad Journal of Agriculture, 23 (4): 1127-1130.

[37] Sinha, K. (2012). 70\% of milk in Delhi, country is adulterated consultancy Report http://timesofindia.indiatimes.com/topic/FoodSafety-Standards-Authority- of-India.

[38] Goswami, T.K., \& Gupta, S.K. (2008). Detection of dilution of milk with the help of glass transition temperature by differential scanning calorimetry (DSC). African Journal of Food Science, 2, 7-10.

[39] Naz, W. (2000). Subject: The dairy sector. http://www. Pakistaneconomist.com. Accessed Feb. 2011.

[40] Yildiz, A., Erdogan, S., Saydut, A. \& Hamamci, C. (2012). High-Performance Liquid Chromatography analysis and assessment of benzoic acid in yogurt, ayran, and cheese in Turkey. Food Analytical Methods. (5): 591-595.

[41] Gale, F., \& Hu, D. (2007). Supply chain issues in China's milk adulteration incident. Economic Research Service U. S. Department of Agriculture Washington, DC.

[42] Sanjeevani, B.W., Chavan, B.R. \& Menkudale, G.V. (2011). Survey on adulteration of the milk received from Government milk scheme in banded town. Journal of International link Research Analysis, 1 (4): 32-35. 